\title{
The Efficacy of Recombinant Human Erythropoietin in Pregnant Patients with Iron Deficiency Anemia
}

\author{
LAMIAA M. AL-AHWAL, M.D.*; SAHAR M. HAZZAA, M.D.**; ABD EL-GAFAR S. DAWOOD, M.D.* and \\ HEBA A. SELIM, M.Sc.* \\ The Departments of Obstetrics \& Gynecology* and Clinical Pathology**, Faculty of Medicine, Tanta University
}

\begin{abstract}
Background: Gestational anemia increases the incidence of maternal and fetal complications. Adjuvant recombinant human erythropoietin (rHuEPO) has been used in patients who refuse blood transfusions, have a low response to treatment with iron iron sucrose, have limited time before birth, or have other illnesses that complicate the anemia. We demonstrated that the use of adjuvant $\mathrm{rHuEPO}$ with iron sucrose reduces the anemia time period and is innocuous to the fetus.
\end{abstract}

Aim of the Study: To evaluate the efficacy of Recombinant Human Erythropoietin in the pregnant Patients with Iron Deficiency Anemia.

Patients and Methods: This is a prospective study including 70 pregnant women with iron deficiency anemia attending to the out-patient clinic of the department of Obstetric and Gynecology of Tanta University Hospital from June 2016 till June 2017. Divided into two groups, Group (A) Include (35) patients; received $200 \mathrm{mg}(10 \mathrm{ml})$ iron sucrose intravenously twice weekly. Group (B) Include (35) patients; received 200 $\mathrm{mg}$ iron sucrose intravenously twice weekly and reco mbinant human erythropoietin (rhEPo) subcutaneous twice weekly.

Results: We found that group B shows higher level of serum iron than group $\mathrm{A}$ in second sample but differences still insignificant $p$-value 0.077 . But group B shows lower level of serum ferritin than group A in the same sample and the difference is significant $p$-value 0.042 but it had higher level $\mathrm{Hb}$ level \& Hematocrite \& $\mathrm{MCH}$ and Reticulocytic count. The mean $\mathrm{Hb}$ level was $11 \mathrm{~g} / \mathrm{dl}$ ranging from (10.5 to $11.5)$ and $11.7 \mathrm{~g} / \mathrm{dl}$ ranging from (10.8 to 12.6$)$ in group $\mathrm{A} \& \mathrm{~B}$ respectively.Hemoglobin levels are raisied by up to $2.7 \mathrm{~g} / \mathrm{dL}$ and $3.2 \mathrm{~g} / \mathrm{dL}$ in group $\mathrm{A} \& \mathrm{~B}$ respectively.

Conclusion: The use of adjuvant recombinant human erythropoietin can safely enhance the efficacy of iron sucrose in the treatment of gestational iron-deficiency anemia that did not respond to oral supplementation.

Key Words: Recombinant human erythropoietin - AnemiaPergnancy - Iron deficiency.

Correspondence to: Dr. Lamiaa M. Al-Ahwal, The Department of Obstetrics \& Gynecology, Faculty of Medicine, Tanta University

\section{Introduction}

IRON deficiency anemia (IDA) continues to be the commonest etiology of anemia in pregnancy. The prevalence of iron deficiency (ID) in pregnant Indian women is amongst the highest in the world. Untreated iron deficiency (ID) has significant adverse feto-maternal consequences. Plethora of investigations are available for diagnosis of IDA, each having specific advantages and disadvantages when used in the pregnancy setting. Therapy for ID includes dietary modification, oral iron supplementation, intravenous iron and blood transfusion. Newer parenteral iron preparations are safe and there is mounting evidence to suggest their use in frontline settings for pregnancy associated IDA in the second and third trimester [1].

Isolated IDA can often be prevented by iron supplementation and, once it has manifested, is preferentially treated by oral iron salts. Parenteral iron treatment is an alternative to consider, especially when a rapid correction is needed, or gastrointestinal malabsorption or active inflammatory disease dampens dietary iron absorption in anemia of chronic disease $[2,3]$

In patients with intolerance to oral iron therapy, parenteral iron is the treatment of choice. Many subjects with ACD who are under causative treatment for their underlying condition do not have an adequate hemoglobin $(\mathrm{Hb})$ response to iron therapy. The erythropoietin (EPO) resistance of the erythron or renal EPO deficiency may be present, such that recombinant human erythropoietin (rhEPO) therapy should be considered as addon therapy for anemia [4].

In pregnant women with moderate and severe anemia, parenteral administration of iron potentially 
in combination with rhEPO can be an important alternative; it also provides quick and efficient correction of the total iron deficit because it not only corrects the anemia, but also builds up iron stores [5].

\section{Aim of the study:}

To evaluate the efficacy of Recombinant Human Erythropoietin in the pregnant Patients with Iron Deficiency Anemia.

\section{Patients and Methods}

This is a prospective study including 70 pregnant women with iron deficiency anemia attending to the out-patient clinic of the department of Obstetric and Gynecology of Tanta University Hospital from June 2016 till June 2017.

The patients has been divided into two groups Group (A) Include (35) patients; received 200mg $(10 \mathrm{ml})$ iron sucrose intravenously twice weekly. Group (B) Include (35) patients; received 200mg iron sucrose intravenously twice weekly and recombinant human erythropoietin (rhEPo) subcutaneous twice weekly.

Inclusion criteria: Patients aged between 20 years to 35 years. Primigravida. Pregnant with single fetous. Subjects had iron deficiency anemia, i.e., an $\mathrm{Hb}$ level ${ }^{<9}$ gram\%. Serum ferritin level $<15$ microgram/liter.

Exclusion criteria: Women with anemia from causes other than iron deficiency (e.g. infection, chronic bleeding or renal failure). Multiparity and multiple pregnancy. Previous blood transfusion. History of hematologic disease (e.g. thalassemia or sickle cell disease). History of iron or rhEPO intolerance.

\section{All Patients were subjected to the following:}

- Personal history: Age, occupation, residency and special habits. Present history of systemic diseases: Diabetes Melliteus and Hypertension. Obstetric history and gestational age. Past history of chronic medical disease, drug therapy and allergy. Family history of similar conditions.

- All patients received oral iron supplements (iron sulfate daily) as a routine basis since the beginning of the second trimester, but developed anemia. Minimum duration of oral iron supplementation was 4 weeks, before intravenous therapy to be commenced. Blood samples were taken before therapy for routine hematologic examination (complete blood picture serum iron serum ferritin).
- Hematological parameters including: complete blood picture (hemoglobin $(\mathrm{Hb}) \&$ RBCs count \& reticulocytic count and Hematocrite \%) Evaluation of red cell indices including: Haematocrite level, Mean corpuscular volume (MCV), Mean Corpuscular Hemoglobin (MCH), Mean corpuscular hemoglobin concentration (MCHC).

\section{Iron indices:}

Iron status assessment for each patient was assessed using biochemical tests including estimation of iron (micro g/dl) using colorimetric kits.

Serum Ferritin level by ELISA method (A normal ferritin blood level, referred to as the reference interval is determined by many testing laboratories.

\section{Follow-up:}

Blood samples will be taken every two weeks during the duration of therapy for determination of iron status [serum iron level and serum ferritin level]. Duration of therapy: 4 weeks.

\section{Results}

Total of 70 cases included divided into two groups were matched in age, GA and BMI as there was insignificant differences between the two groups regarding age, GA, BMI $p$-value 0.657 , $0.197,0.433$ respectively (Table 1 ). That there was insignificant differences between the two groups as regard serum iron, serum ferritin level, hemoglobin, hematocrit value, $\mathrm{MCV}, \mathrm{MCH}, \mathrm{MCHC}$ and reticulocytic count in the first sample.

Group B shows higher level of serum iron than group $\mathrm{A}$ in second sample but differences still insignificant $p$-value 0.077 . But group B shows lower level of serum ferritin than group A in the same sample and the difference is significant $p$ value 0.042 . CBC at second sample shows no statistical differences between two groups except in regarding to reticulocytic count there was significant differences as its level was higher in group B $p$-value $<0.001$.

In the third sample we found that group B has lower levels for both serum iron and serum ferritin than group $\mathrm{A}$ in the third sample and the difference is significant $p$-value $0.005,0.034$ respectively. Group B has higher level than Group A as regard $\mathrm{Hb}$ level \& Hematocrite \& $\mathrm{MCH}$ and Reticulocytic count in the third sample and it is significant ( $p$ value $0.003-0.002-0.041-0.004)$ respectively (Tables 1,2, Figs. 1,2).

In comparison between the repeated measurements of $\mathrm{Hb}$, hematocrite, $\mathrm{MCV}, \mathrm{MCH}, \mathrm{MCHC}$ in 
group A there was significant differences between the three repeated sample in group $\mathrm{A}$ as regard $\mathrm{Hb}$, ferritin, MCV, MCHC $p$-value $<0.001,<0.001$, $<0.001,0.039$. In comparison between the repeated $\mathrm{Hb}$, hematocrite, $\mathrm{MCV}, \mathrm{MCH}, \mathrm{MCHC}$ in group $\mathrm{B}$ there was significant differences between the repeated samples of $\mathrm{Hb}$, hematocrite, $\mathrm{MCV}, \mathrm{MCH}$, $\mathrm{MCHC}$ in group $\mathrm{B}$.

In comparison between the repeated iron, hematocrit, reticulocytic count in group A there was significant differences between the repeated samples of iron, hematocrit, reticulocytic count in group $\mathrm{A}$, in comparison between the repeated iron, hematocrit, reticulocytic count group B there was significant differences between three repeated samples of hematocrite and reiculocytic count in group B but there was insignificant differences between three samples as regard serum iron.

As regard side effects occurred among patients side effect occurred in group A more than group $\mathrm{B}$ in the form of allergic reaction, GI upset, metallic taste and there was insignificant differences between two groups as regard side effect with $p$ value 0.147 .

\begin{tabular}{|c|c|c|c|c|c|}
\hline & \multicolumn{3}{|c|}{ Group } & \multicolumn{2}{|c|}{ Tests of significance } \\
\hline & $\begin{array}{l}\text { Group A } \\
(\mathrm{N}=35)\end{array}$ & $\begin{array}{c}\text { Group B } \\
(\mathrm{N}=35)\end{array}$ & $\begin{array}{c}\text { Total } \\
(\mathrm{N}=70)\end{array}$ & Test statistic & $p$-value \\
\hline \multicolumn{6}{|l|}{$H b \%:$} \\
\hline Minimum & 10.7 & 10.4 & 10.4 & $\mathrm{Z}_{\mathrm{MW}}=1.770$ & $0.003 *$ \\
\hline Maximum & 11.5 & 12.6 & 12.6 & & \\
\hline Median & 11.0 & 11.7 & 11.0 & & \\
\hline IQR & $10.5-11.5$ & $10.8-12.6$ & $10.9-11.3$ & & \\
\hline Mean ranks & 31.3 & 39.7 & & & \\
\hline \multicolumn{6}{|l|}{ Haematocrite: } \\
\hline Minimum & 35.6 & 38.6 & 35.6 & $t=1.287$ & $0.002 *$ \\
\hline Maximum & 44.9 & 47.0 & 47.0 & & \\
\hline Mean & 39. & 41.4 & 40.5 & & \\
\hline Standard deviation & 3.2 & 3.8 & 3.5 & & \\
\hline \multicolumn{6}{|l|}{$M C V:$} \\
\hline Minimum & 65.0 & 77.2 & 65.0 & $\mathrm{Z}_{\mathrm{MW}}=-1.863$ & 0.061 \\
\hline Maximum & 90.6 & 91.8 & 91.8 & & \\
\hline Median & 80.4 & 84.8 & 82.0 & & \\
\hline IQR & $72.9-88.0$ & $80.6-90.0$ & $78.4-88.6$ & & \\
\hline Mean ranks & 30.99 & 39.39 & & & \\
\hline \multicolumn{6}{|l|}{ MCH: } \\
\hline Minimum & 20.0 & 26.7 & 20.0 & $\mathrm{Z}_{\mathrm{MW}}=-2.146$ & $0.041 *$ \\
\hline Maximum & 33.5 & 33.7 & 33.7 & & \\
\hline Median & 28.8 & 30.4 & 29.0 & & \\
\hline IQR & $26.0-31.0$ & $28.6-32.8$ & $27.5-32.0$ & & \\
\hline Mean ranks & 30.34 & 39.87 & & & \\
\hline \multicolumn{6}{|l|}{$M C H C:$} \\
\hline Minimum & 29.4 & 30.1 & 29.4 & $\mathrm{Z}_{\mathrm{MW}}=-1.405$ & 0.160 \\
\hline Maximum & 36.3 & 38.9 & 38.9 & & \\
\hline Median & 33.0 & 34.1 & 33.0 & & \\
\hline IQR & $30.8-34.5$ & $32.7-35.8$ & $32.0-34.0$ & & \\
\hline Mean ranks & 36.42 & 38.21 & & & \\
\hline \multicolumn{6}{|l|}{ Reticulocytic count: } \\
\hline Minimum & 1.2 & 1.8 & 1.2 & $t=-0.687$ & $0.004 *$ \\
\hline Maximum & 2.5 & 2.9 & 2.9 & & \\
\hline Mean & 2. & 2.2 & 1.5 & & \\
\hline Standard deviation & 0.3 & 0.4 & 0.4 & & \\
\hline
\end{tabular}


Table (2): Serum iron and ferritin ( $3^{\text {rd }}$ sample).

\begin{tabular}{|c|c|c|c|c|c|}
\hline & \multicolumn{3}{|c|}{ Group } & \multicolumn{2}{|c|}{ Tests of significance } \\
\hline & $\begin{array}{c}\text { Group A } \\
(\mathrm{N}=35)\end{array}$ & $\begin{array}{c}\text { Group B } \\
(\mathrm{N}=35)\end{array}$ & $\begin{array}{c}\text { Total } \\
(\mathrm{N}=70)\end{array}$ & Test statistic & $p$-value \\
\hline \multicolumn{6}{|l|}{ Serum iron: } \\
\hline Minimum & 54.0 & 35.8 & 35.0 & $t=2.574$ & $0.005^{*}$ \\
\hline Maximum & 166.0 & 130.0 & 166.0 & & \\
\hline Mean & 100.5 & 88.8 & 94.7 & & \\
\hline Standard deviation & 32.6 & 30.7 & 31.4 & & \\
\hline \multicolumn{6}{|l|}{ Serum ferritin: } \\
\hline Minimum & 8.0 & 3.5 & 3.5 & $\mathrm{Z}_{\mathrm{MW}}=2.123$ & $0.034 *$ \\
\hline Maximum & 96.0 & 34.0 & 96.0 & & \\
\hline Median & 43.97 & 29.0 & 23.0 & & \\
\hline IQR & $17.5-38.4$ & $16.0-27.0$ & $17.0-33.0$ & & \\
\hline Mean ranks & 43.97 & 29.43 & & & \\
\hline
\end{tabular}

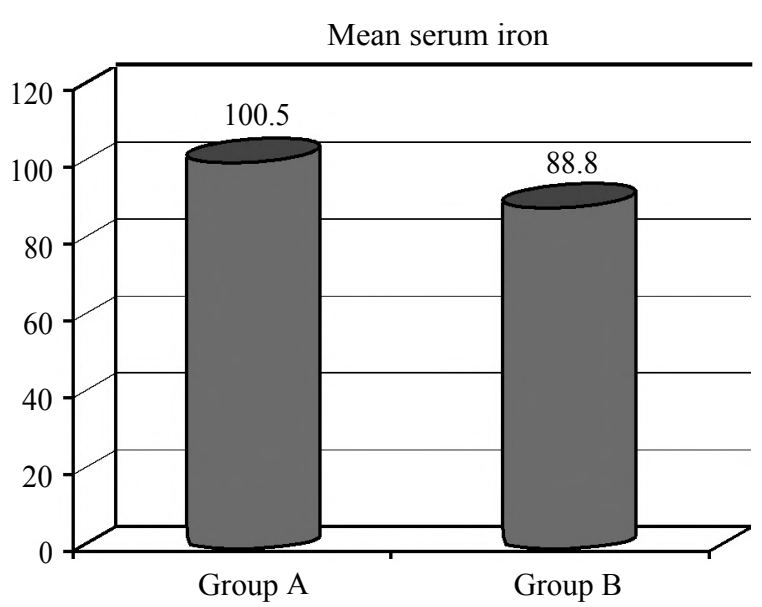

Fig. (1): Comparison between the two groups as regard serum iron $3^{\text {rd }}$ sample.

\section{Discussion}

Iron deficiency anemia (IDA) in pregnancy is an urgent problem of modern practical obstetrics due to high prevalence of this pathology. The deleterious effects of IDA on pregnancy course and outcome, long-term character of routine therapy, great number of treatment-refractory cases, and complications aggravated by side effects clearly define the task to improve the effectiveness of IDA treatment in pregnant women. To find effective tools to correct this pathology [6]. The present study found that, the studied groups are matched in age, GA and BMI as there was insignificant difference between the two groups regarding age, GA, BMI ( $p$-value $0.657,0.197,0.433$ ) respectively.

Also there was insignificant difference between the two groups as regard the first sample of hemoglobin, hematocrit value, $\mathrm{MCV}, \mathrm{MCH}, \mathrm{MCHC}$ and reticulocytic count. In the second sample; after 2 weeks of parentral iron therapy, there are no statistical differences between the two groups except

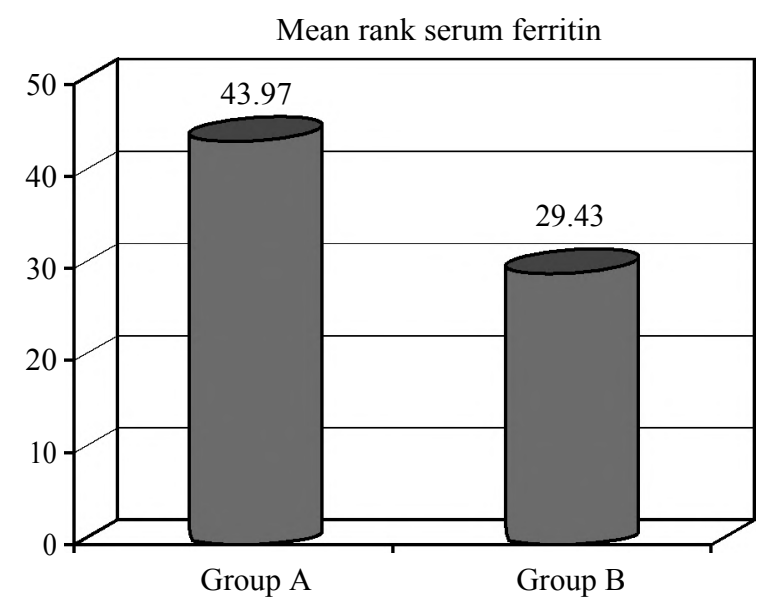

Fig. (2): Comparison between the two groups as regard serum ferritin $3^{\text {rd }}$ sample.

in regarding to the reticulocytic count, there is a significant difference as its level was higher in group $\mathrm{B} p$-value $<0.001$.

In the third sample; after 2 weeks of parentral iron and recombinant human erythropoietin therapy, Group B show a significant increase in the $\mathrm{Hb}$ level \& Hematocrite value \& $\mathrm{MCH}$ and Reticulocytic in comparable to Group A. ( $p$-value 0.0030.002-0.041-0.004) respectively. The mean $\mathrm{Hb}$ level was $11 \mathrm{~g} / \mathrm{dl}$ ranging from (10.5 to 11.5$)$ and $11.7 \mathrm{~g} / \mathrm{d}$ l ranging from (10.8 to 12.6) in group $\mathrm{A} \& \mathrm{~B}$ respectively.Hemoglobin levels are raisied by up to $2.7 \mathrm{~g} / \mathrm{dL}$ and $3.2 \mathrm{~g} / \mathrm{dL}$ in group A \& B respectively.

In agreement with the present study Bencaiova et al., (2017) in a prospective study set in the Anemia Clinic at the Department of Obstetrics, Zurich University Hospital on Fifty anemic pregnant women with moderate anemia. All patients had singleton pregnancies. All pregnant women fulfilled the criteria of moderate iron deficiency anemia defined as hemoglobin between 8.0 and $9.9 \mathrm{~g} / \mathrm{dl}$ and serum ferritin $<15 \mathrm{~g} / \mathrm{l}$ The women 
were treated either with intravenous iron and rhEPO or with intravenous iron only twice weekly [7] .

All patients showed stimulation of erythropoiesis as evidenced by an increase in reticulocyte count at day eight of therapy and showed an increase in hemoglobin and hematocrit at the end of therapy $(p<0.001)$. The target hemoglobin $(>10.5 \mathrm{~g} /$ dl) was achieved in 45/50 women (90\%). 12 patients showed anemia of chronic disease with true iron deficiency $(12 / 50,24 \%)$, responded well to intravenous iron, and $76 \%$ responded well to the combination of intravenous iron and recombinant human erythropoietin [7].

In disagreement with the results of the present study, Wågström et al.,(2007) in a prospective, randomized, pilot study, consisting of 60 pregnant women at 2 hospitals in Stockholm and Sweden, between November 1999 and May 2001 with haemoglobin level $>80 \mathrm{~g} / \mathrm{l}$ and divided into 3 different treatment groups. All 3 groups received iv iron sucrose, $250 \mathrm{mg}$ on day 1 , and $200 \mathrm{mg}$ on day 4 . In addition, 2 groups received rhEPO in doses of 10,000 or $20,000 \mathrm{IU}$ on day 1 and day 4 . RhEPO was injected subcutaneously [8]

All women were advised to take supplementary iron, $100 \mathrm{mg}$ daily. After 1 week, they determined haemoglobin and haematocrit value. Duration of therapy was 4 times over a 2-week period. They demonstrated that; Haemoglobin increased significantly in all 3 groups $(p>0.001)$, but there were no differences between the different treatment groups ( $p=0.589$ ). The total haemoglobin increase for all subjects after 1 week (given as mean (standard deviation) was $18 \mathrm{~g} / \mathrm{l}$ and after 2 weeks, $28 \mathrm{~g} / \mathrm{l}$. Showed that the treatment with rhEPO gave no additional increase in haemoglobin concentration compared to intravenous iron alone [8]

Concerning the iron status; the present study show that, Group B has lower levels for both serum iron and serum ferritin than group A and the difference is significant ( $p$-value $0.005,0.034$ ) respectively.In agreement with the present study, krafft et al., (2009) found that, the values of serum ferritin are lower in those patients treated with rhEPO and iron sucrose from the beginning of the therapy [9].

Krafft A et al., (2009) supported that, a limiting factor for an effective correction of anemia with rHuEPO is the insufficient iron levels. Moreover, adequate iron stores is an important prerequisite for a successful $\mathrm{rHuEPO}$ treatment [9].
Moreover Sifakis et al., (2001) supported that, Parenteral iron administration and rhEPO therapy caused a decrease of ferritin levels after the 4 weeks' therapy in the successfully treated patients [10].

Concerning to the safety of the protocol of therapy, the present study show that, the side effects occurred are in the form of allergic reaction, GI upset, metallic taste in group A, adding minor skin rash and flu-like illness in group B, with no significant difference between the two groups with $p$ value 0.607 . There was no correlation between the side effects occurred in the two groups and the type of therapy.

In agreement, Breymann C et al., (2001) stated that, There were minor reactions to rhEPO and iron sucrose. Three patients reported a metallic taste, and 2 reported feeling warm for a few minutes. No hypotensive or hypertensive responses were seen during or after therapy. No thromboembolic complications were seen [11]

Also Bencaiova et al., (2017) showed that, Side-effects (hypotensive and hypertensive response, allergic reaction, and thromboembolic complications) were registered. And most patients reported a metallic taste during iron sucrose infusion $[7]$

In contrary, krafft A et al., (2009) reported that, There were no serious adverse events in all three groups. No hypotensive responses, allergic reactions, or thromboembolic complications were seen during therapy [9] .

\section{Conclusion:}

The use of adjuvant recombinant human erythropoietin can safely enhance the efficacy of iron sucrose in the treatment of gestational iron-deficiency anemia that did not respond to oral supplementation.

\section{References}

1- TANDON R, JAIN A. and MALHOTRA P.: Management of Iron Deficiency Anemia in Pregnancy in India. Indian J. Hematol. Blood Transfus, 34: 204, 2018.

2- CEPEDA-LOPEZ A.C., MELSE-BOONSTRA A., ZIMMERMANN M.B., et al.: In overweight and obese women, dietary iron absorption is reduced and the enhancement of iron absorption by ascorbic acid is one-half that in normal-weight women. American Journal of Clinical Nutrition, 102 (6): 1389-1397, 2015.

3- NIELSEN O.H., AINSWORTH M., COSKUN M., et al.: Management of Iron-Deficiency Anemia in Inflammatory Bowel Disease: A Systematic Review. Medicine (United States), 94 (23): p. 963, 2015. 
4- WEISS G.: Anemia of chronic disorders: New diagnostic tools and new treatment strategies. Seminars in Hematology, 52 (4): 313-320, 2015.

5- AMSTAD BENCAIOVA G., KRAFFT A., ZIMMERMANN R., et al.: Treatment of Anemia of Chronic Disease with True Iron Deficiency in Pregnancy. Journal of Pregnancy, 4265091, 2017.

6- BURMINA Y.V., UDUT E.V., ZHDANOV V.V., et al.: Mechanisms of Erythropoietin-Stimulating Action of Anti-Erythropoietin Release-Active Antibodies in Complex Treatment of Experimental Anemia during Gestation. Bulletin of Experimental Biology and Medicine, 160 (6): 737-741, 2016.

7- BENCAIOVA A.G., KRAFFT A., ZIMMERMANN R, et al.: Treatment of anemia of chronic disease with true Iron Deficiency in Pregnancy, 1-7, 2017.

8- WÅGSTRÖM E., AKESSON A., VAN ROOIJEN M., et al.: Erythropoietin and intravenous iron therapy in postpartum anaemia. Acta. Obstet. Gynecol. Scand., 86 (8): 957-962, 2007.

9- KRAFFT A, BENCAIOVA G and BREYMANN C.: Selective Use of Recombinant Human Erythropoietin in Pregnant Patients with Severe Anemia or Nonresponsive to Iron Sucrose Alone. Fetal. Diagn. Ther., 25: 239-245, 2009.

10- SIFAKIS S., ANGELAKIS E., VARDAKI E., et al.: Erythropoietin in the Treatment of Iron Deficiency Anemia during Pregnancy. Gynecol. Obstet. Invest., 51: 150-156, 2001.

11- BREYMANN C., VISCA E., HUCH R., et al.: Efficacy and safety of intravenously administered iron sucrose with and without adjuvant recombinant human erythropoietin for the treatment of resistant iron-deficiency anemia during pregnancy. Am. J. Obstet. Gynecol., 184 (4): 662-667, 2001.

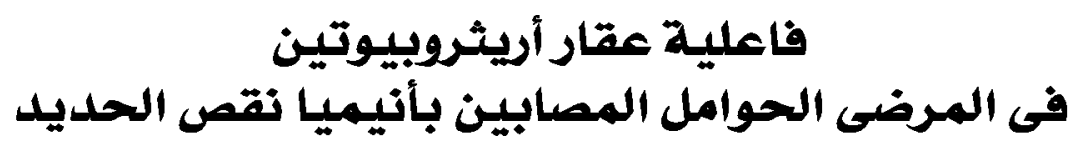

أنيميا نقص الصديد هر النوع الاكثر ثيوعاً من فقر الدم أثناء الحمل وبعد الولادة وفقاً لتقرير منظمة الصحة العالمية. زيادة متطلبات

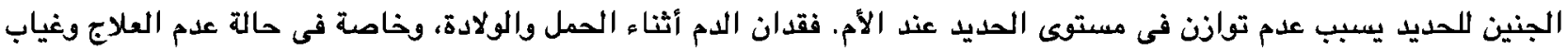

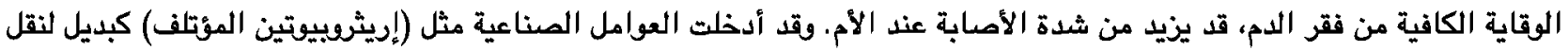

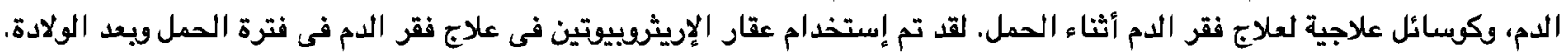

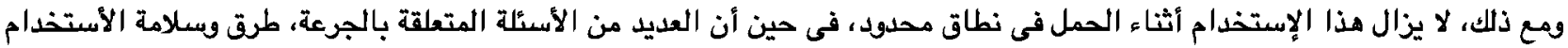

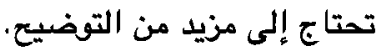

تم إجراء هذه الدراسة على (•V) أمرأة حامل تم أحتيارهن من بين الذين يحضرون إلى قعم النساء والولادة بمستشفى الجامعة :

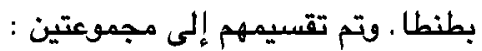

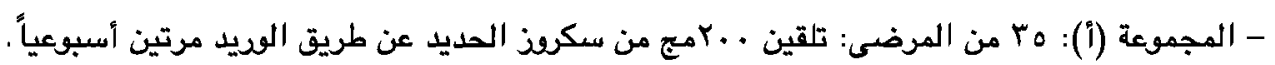

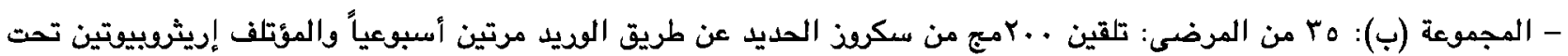
الجلد مرتين أسبوعياً.

وكانت المجموعتين عموماً قد تلقت مكملات الحديد عن طريق الفم (YV إمج) من مركبات الحديد يومياً كأساس روتينى منذ بداية

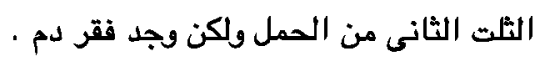

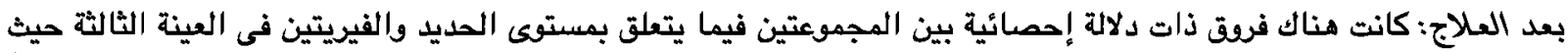

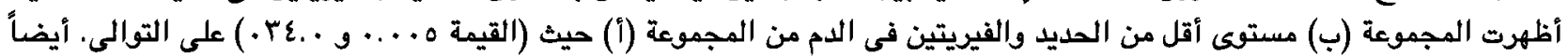

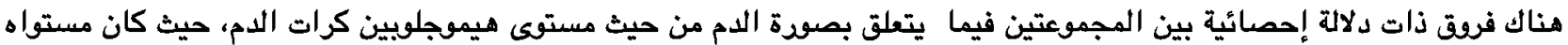

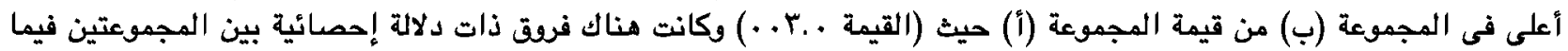

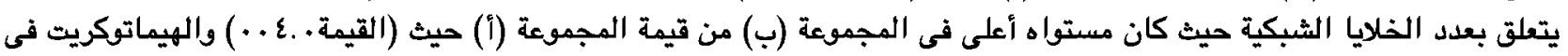

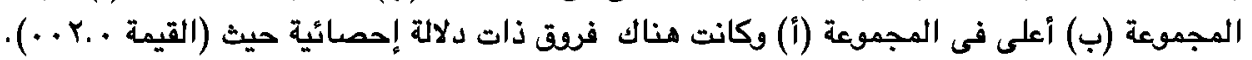

- فى المجموعة (أ): وكانت هناك فروق ذات دلالة إحصائية بين ثلاث عينات متكررة فى قيم الهيموجلوبين والفيريتين. - فى المجموعة (ب):وكانت هناك فروق ذات دلالة إحصائية بين ثلاث عينات متكررة فى قيم الهيموجلوبين والهيماتوكريت وعدد الخلايا الثبكية. 